Article

\title{
The High Content of Ent-11 $\alpha$-hydroxy-15-oxo-kaur- 16-en-19-oic Acid in Adenostemma lavenia (L.) O. Kuntze Leaf Extract: With Preliminary in Vivo Assays
}

\author{
Akie Hamamoto, Ryosuke Isogai, Miwa Maeda, Masumi Hayazaki, Eito Horiyama, \\ Shigeo Takashima $\mathbb{D}$, Mamoru Koketsu $\mathbb{D}$ and Hiroshi Takemori *(D) \\ Department of Chemistry and Biomolecular Science, Faculty of Engineering, Gifu University, 1-1 Yanagido, \\ Gifu 501-1193, Japan; ahama@gifu-u.ac.jp (A.H.); y4521005@edu.gifu-u.ac.jp (R.I.); \\ v3032132@edu.gifu-u.ac.jp (M.M.); v3032126@edu.gifu-u.ac.jp (M.H.); y4524067@edu.gifu-u.ac.jp (E.H.); \\ staka@gifu-u.ac.jp (S.T.); koketsu@gifu-u.ac.jp (M.K.) \\ * Correspondence: htake@gifu-u.ac.jp
}

Received: 21 November 2019; Accepted: 7 January 2020; Published: 9 January 2020

\begin{abstract}
Background: Ent-11 $\alpha$-hydroxy-15-oxo-kaur-16-en-19-oic acid (11 $\alpha \mathrm{OH}-\mathrm{KA})$ is a multifunctional biochemical found in some ferns, Pteris semipinnata, and its congeneric species. Although a number of therapeutic applications of $11 \alpha \mathrm{OH}-\mathrm{KA}$ have been proposed (e.g., anti-cancer, anti-inflammation, and skin whitening), the content of $11 \alpha \mathrm{OH}-\mathrm{KA}$ in these ferns is not high. Adenostemma lavenia (L.) O. Kuntze, an Asteraceae, has also been reported to contain $11 \alpha \mathrm{OH}-\mathrm{KA}$. The decoction (hot water extract) of whole plants of $A$. lavenia is used as a folk remedy for inflammatory disorders, such as hepatitis and pneumonia, suggesting that $11 \alpha \mathrm{OH}-\mathrm{KA}$ may be the ingredient responsible for the medicinal properties of this plant. Methods: The anti-melanogenic activities of the water extracts of A. lavenia leaves and Pteris dispar Kunze (a cognate of P. semipinnata) leaves were compared in mouse B16F10 melanoma cells. The amount of $11 \alpha \mathrm{OH}-\mathrm{KA}$ was measured by using liquid chromatography spectrometry. C57BL/6J mice were treated with the water extract of A. lavenia leaf, and the blood concentration of $11 \alpha \mathrm{OH}-\mathrm{KA}$ was measured. The in vivo efficacy of the water extract of A. lavenia leaf was evaluated according to tis anti-melanogenic activity by monitoring hair color. Results: Although both the extracts (A. lavenia and P. dispar Kunze) showed high anti-melanogenic activities, only A. lavenia contained a high amount of $11 \alpha \mathrm{OH}-\mathrm{KA}$, approximately $2.5 \%$ of the dry leaf weight. $11 \alpha \mathrm{OH}-\mathrm{KA}$ can be purified from $A$. lavenia leaves in two steps: water extraction followed by chloroform distribution. The treatment of mice with the water extract of $A$. lavenia leaf suppresses pigmentation in their hairs. Conclusions: Despite the small number of mice examined, the present preliminary result of the suppressed hair pigmentation suggests that the water extract of A. lavenia leaf and the ingredient that is possibly responsible for this- $11 \alpha \mathrm{OH}-\mathrm{KA}$ - are new materials for oral cosmetics. The results may also be helpful in the future development of functional foods and methods to treat patients suffering from hyperpigmentation disorders, such as melasma.
\end{abstract}

Keywords: $11 \alpha$-hydroxy-15-oxo-kaur-16-en-19-oic acid; anti-melanogenesis; skin whitening; functional food; medical plant; Adenostemma lavenia; Pteris dispar Kunze; tyrosinase; B16F10 melanoma

\section{Introduction}

Studies on anti-melanogenic reagents for skin whitening and anti-aging have become more frequent, especially for ingredients in foods (fruits, vegetables, and medical herbs) [1]. A number of polyphenols and terpenes and their sources have been developed and commercialized as functional foods and supplements. 
The diterpene/kaurene ent-11 $\alpha$-hydroxy-15-oxo-kaur-16-en-19-oic acid (11 $\alpha \mathrm{OH}-\mathrm{KA})$, found in the leaves of ferns (Pteris semipinnata [2-5], Pteris livida [6]) and Compositae (Gochnatia decora [7]), is also an attractive candidate for anti-melanogenic reagents [5]. Despite its broad physiological activities (e.g., anti-cancer and anti-inflammation) [8-11], there are only a few records on the in vivo efficacy of $11 \alpha \mathrm{OH}-\mathrm{KA}$, including its anti-melanogenic potential, likely due to its rarity and restricted number of sources.

Structure-activity relationship studies, both in vitro and in cultured cells, have identified the moieties in $11 \alpha \mathrm{OH}-\mathrm{KA}$ important for exerting its functional activities (Figure 1). Replacement of the carboxy group at the 19th position in $11 \alpha \mathrm{OH}-\mathrm{KA}$ by methyl or hydroxy groups converts this compound to a compound with high anti-cancer activities, which indicates that the 19-carboxyl group weakens the cellular toxicity of this compound $[5,10,12]$. In contrast, the alkene group at the 16th position, the ketone group at the 15th position, and the hydroxy group at the $11 \alpha$ position enhance the apoptotic activities by activating the Caspase signaling pathway $[10,12]$. However, these moieties are not indispensable for the cell death signals of kaurenes. The structural requirements for anti-inflammatory activity are similar to those for anti-cancer activity, suggesting crosstalk via common cellular targets, such as nuclear factor kappa B (NF-kB) [12].

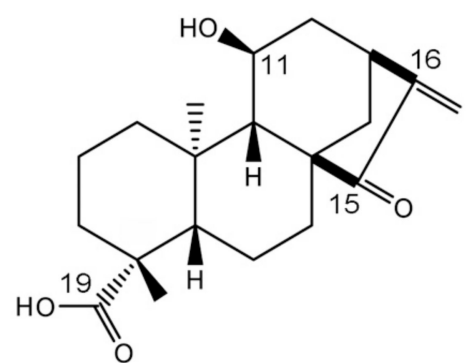

Figure 1. The structure of ent-11 $\alpha$-hydroxy-15-oxo-kaur-16-en-19-oic acid (11 $\alpha \mathrm{OH}-\mathrm{KA})$.

Tyrosinase is a rate-limiting enzyme in melanin synthesis $[13,14]$. The enzyme catalyzes sequential reactions: the conversion of tyrosine to L-3,4-dihydroxyphenylalanine, L-Dopa, and then to dopaquinone. We have reported that $11 \alpha \mathrm{OH}-\mathrm{KA}$ inhibits the expression of the tyrosinase gene, which results in a suppression of melanogenesis in B16F10 mouse melanoma cells [5]. The moieties of 11 $\alpha$-hydroxy, 15-oxo, and 16-en in $11 \alpha \mathrm{OH}-\mathrm{KA}$ are indispensable for its anti-melanogenesis activity, which is a different characteristic of the structural requirements of $11 \alpha \mathrm{OH}-\mathrm{KA}$ compared to other activities, such as anti-cancer or anti-inflammatory activities.

Thus, in terms of its anti-melanogenic activity, $11 \alpha \mathrm{OH}-\mathrm{KA}$ is a unique compound among kaurenes. Unfortunately, Pteris dispar Kunze, our previous source of $11 \alpha \mathrm{OH}-\mathrm{KA}$, contained only a small amount of this compound [5], and this fern, as well as P. semipinnata (a cognate) [4,15], has no record of usage in human subjects. Moreover, in all past experiments, organic solvents (methyl or ethyl alcohol, chloroform, or hexane) were used to extract $11 \alpha \mathrm{OH}-\mathrm{KA}$, without any records of the usage of aqueous extraction.

Almost 40 years ago, an American group discovered $11 \alpha \mathrm{OH}-\mathrm{KA}$ and its derivatives in Adenostemma lavenia (L.) O. Kuntze (an Asteraceae) [16]. Although A. lavenia has not been studied sufficiently regarding the risk of possible contaminants (e.g., inorganic pollutants [17] and secondary metabolites produced by fungi $[18,19]$ ) in leaves and other parts, whole plant powder (named Ma Zhi Hu) is sold in the United States under the permission of medical doctors (the products can be obtained from QualiHerb, Cerritos, CA, USA: Supplementary Materials Figure S1). Therefore, in this study, by measuring the $11 \alpha \mathrm{OH}-\mathrm{KA}$ content and evaluating the efficacy of its anti-melanogenic activities, we examined the potential of a water extract of A. lavenia leaf for use in internal cosmetics, as well as a new category of functional foods [20-22] that may be used to treat patients suffering from hyperpigmentation disorders such as melasma. To date, only tranexamic acid (a hemostatic drug) has been available as an internal drug for hyperpigmentation disorders [23,24]. 
We report here that $A$. lavenia leaves contain $11 \alpha \mathrm{OH}-\mathrm{KA}$ at high levels (approximately $2.5 \%$ of the dry weight of leaves). The water extract of the A. lavenia leaf efficiently suppresses melanogenesis in B16F10 cells, and $11 \alpha \mathrm{OH}-\mathrm{KA}$ may be responsible for $50 \%$ of the anti-melanogenic activities of the water extract. The oral treatment of mice with the water extract of $A$. lavenia leaf results in the suppression of their hair pigmentation.

\section{Materials and Methods}

\subsection{Propagation of A. lavenia}

Since A. lavenia is listed as an endangered species in most areas of Japan, we cultured this plant in a field near our laboratory. A. lavenia was propagated by division from 10 seedlings, and almost $100 \mathrm{~g}$ of dried leaves harvested from June to July 2019 was used in this study.

\subsection{Purification of $11 \alpha \mathrm{OH}-\mathrm{KA}$ from Water Extracts and Its Analysis}

Pure $11 \alpha-\mathrm{OH}$ KA (authentic) was purchased from BioBioPha (Shanghai, China). Dried leaf powder $(100 \mathrm{mg})$ obtained from the leaves of A. lavenia or P. dispar Kunze was soaked in $1 \mathrm{~mL}$ of distilled water (for a 10-volume extraction) for $12 \mathrm{~h}$, and the residuals were removed by centrifugation at 12,000 rpm for $10 \mathrm{~min}$. The resulting extracts were analyzed by high-performance (HP) liquid chromatography (LC) using a $\mathrm{C}_{18}$ ODS column $(4.6 \mathrm{~mm} \times 50 \mathrm{~mm}$ : RP-18 GP, Kanto Kagaku, Tokyo, Japan) with a gradient ranging from $40 \%$ methanol/water to $100 \%$ methanol over $10 \mathrm{~min}$. The $11 \alpha-\mathrm{OH}$ KA detection was performed by determining the ultraviolet (UV) absorption at $245 \mathrm{~nm}\left(\mathrm{~A}_{245}\right)$. For 20-, $30-$, and 50 -volume extractions, $50 \mathrm{mg}, 33 \mathrm{mg}$, and $20 \mathrm{mg}$ of dried leaf powder were extracted by $1 \mathrm{~mL}$ of distilled water.

To confirm the structure of $11 \alpha-\mathrm{OH}$ KA in A. lavenia, kaurenoic acid was purified at a semi-large scale. A total of $100 \mathrm{~g}$ of dried A. lavenia leaves was extracted twice from 20 volumes of water, an equi-volume of $\mathrm{CHCl}_{3}$ was added to the water extract of the leaves, and $11 \alpha-\mathrm{OH} \mathrm{KA}$ was recovered from the $\mathrm{CHCl}_{3}$ phase. During the evaporation of the recovered $\mathrm{CHCl}_{3}$ phase, $11 \alpha-\mathrm{OH} \mathrm{KA}$ was precipitated as white crystals. These crystals were recovered by a paper filter. The recovered crystals were analyzed by nuclear magnetic resonance (NMR) $\left({ }^{1} \mathrm{H}-\mathrm{NMR}\left(\mathrm{CDCl}_{3}\right) \delta 0.95(3 \mathrm{H}, \mathrm{s}), 1.28(3 \mathrm{H}, \mathrm{s})\right.$, 1.05-2.22 $(15 \mathrm{H}, \mathrm{m}), 2.37(1 \mathrm{H}, \mathrm{d}, \mathrm{J}=11.9 \mathrm{~Hz}), 3.06(1 \mathrm{H}$, broad s$), 4.06(1 \mathrm{H}, \mathrm{d}, \mathrm{J}=4.6 \mathrm{~Hz}), 5.27(1 \mathrm{H}, \mathrm{s})$, and $5.87(1 \mathrm{H}, \mathrm{s}))$. The ${ }^{1} \mathrm{H}-\mathrm{NMR}$ spectrum of the crystal was coincident with the authentic $11 \alpha-\mathrm{OH}$ KA spectrum (see Supplementary Materials Figure S2).

\subsection{Analysis of $11 \alpha O H-K A$ in Mouse Serum}

Methods for the ultra-performance LC (UPLC)-mass spectrometry (MS) analyses were drawn from several methods used in $[25,26]$. Briefly, to treat mice (C57BL/6J), A. lavenia leaves were extracted with 30 volumes of water. After sterilization at $120^{\circ} \mathrm{C}$ for $20 \mathrm{~min}$, the extract was further diluted with 2 volumes of water and served as drinking water. To examine the pharmacokinetics of $11 \alpha-\mathrm{OH}$ $\mathrm{KA}, 100 \mathrm{mg} / \mathrm{kg}$ of the compound suspended in 1\% Tween 80 (Kanto Kagaku, Tokyo, Japan) was administered orally. Blood was recovered via the tail vein 15-240 min after administration.

To measure the $11 \alpha-\mathrm{OH}$ KA in mouse blood, the serum $(20 \mu \mathrm{L})$ was extracted with $200 \mu \mathrm{L}$ of acetonitrile. To normalize the extraction efficiency, $10 \mathrm{nmols}$ of $18 \beta$-glycyrrhetinic acid (Kanto Kagaku) was added to the serum prior to the extraction. After the removal of acetonitrile by evaporation, the compounds were dissolved in $5 \mu \mathrm{L}$ of methanol followed by the addition of $5 \mu \mathrm{L}$ of $\mathrm{H}_{2} \mathrm{O}$. Then, $1 \mu \mathrm{L}$ of solution was used for LC-MS spectrometry (MS: Waters Xevo G2-XS QTof, Waters, Milford, MA). To separate $11 \alpha-\mathrm{OH}$ KA, a $\mathrm{C}_{18}$ ODS column (3.0 mm $\times 150 \mathrm{~mm}(5 \mu \mathrm{m})$ : RP-18 GP, Kanto Kagaku) and a gradient ranging from $35 \%$ acetonitrile/water to $100 \%$ acetonitrile over $10 \mathrm{~min}$ were applied. The MS conditions were as follows: capillary $(\mathrm{kV}), 2.20$; sampling core, 45; extraction cone, 4.0. Because we failed to detect fragments of $11 \alpha-\mathrm{OH}$ KA via MS/MS analyses (Supplementary Materials Figure S3A), $11 \alpha-\mathrm{OH}$ KA was quantified with only MS signals by monitoring the mass-to-charge ratio $(\mathrm{m} / \mathrm{z})$ of 
331.1879 with the 0.01 Da path (Supplementary Materials Figure S3B). A standard curve was prepared by the addition of $11 \alpha-\mathrm{OH} \mathrm{KA}$ (at a final concentration of $0.1-3 \mu \mathrm{M}$ ) to $50 \%$ methanol/water that had been prepared from normal mouse serum using the same procedure for $11 \alpha-\mathrm{OH} \mathrm{KA}$ extraction. The 18 $\beta$-glycyrrhetinic acid was measured using LC-UV under the same conditions used for the $11 \alpha-\mathrm{OH}$ KA measurement. These animal experiments were approved by the Animal Experiment Committee of Gifu University (H30-041). We used a minimum number of mice to comply with animal welfare requirements.

\subsection{Melanogenesis Assay}

Mouse B16F10 melanoma cells from the American Type Culture Collection (RIKEN, Tsukuba, Japan) were cultured in Dulbecco's modified Eagle's medium (DMEM-High glucose (4.5 g/L D-glucose), WAKO, Kyoto, Japan) and supplemented with $10 \%$ fetal bovine serum and antibiotics. The cells were incubated in a humidified atmosphere with $5 \% \mathrm{CO}_{2}$ at $37^{\circ} \mathrm{C}$ and were transferred every two days via trypsinization to new culture plates.

The cells $\left(2 \times 10^{5}\right)$ were plated onto a 6-well plate and incubated for $12-16 \mathrm{~h}$ prior to the induction of melanogenesis. Melanogenesis was induced by $20 \mu \mathrm{M}$ forskolin (Fsk) together with A. lavenia water extract or $11 \alpha-\mathrm{OH} \mathrm{KA}$ for $48 \mathrm{~h}$. Melanin measurements were performed in accordance with the literature [5]. Briefly, the cells were washed twice with phosphate-buffered saline and recovered in $2 \mathrm{~mL}$ collection tubes, followed by centrifugation at $8000 \mathrm{rpm}$ for $1.5 \mathrm{~min}$. Each cell pellet was suspended in $200 \mu \mathrm{L}$ of distilled water, and $50 \mu \mathrm{L}$ was used for the measurement of protein content. The residual $150 \mu \mathrm{L}$ was mixed with $150 \mu \mathrm{L}$ of $2 \mathrm{M} \mathrm{NaOH}$ and then lysed by incubation at $45^{\circ} \mathrm{C}$ for $2 \mathrm{~h}$. The melanin was extracted with a 2:1 chloroform-methanol mixture and measured with a spectrophotometer (Glomax Multi, Promega, Madison, WI, USA) at $405 \mathrm{~nm}$. The protein concentration of the cell pellets was determined using a Bradford reagent (Bio-Rad, Hercules, CA, USA) and used for normalization of the melanin content.

\subsection{Statistical Analysis}

The statistical analysis was performed using Student's $t$ test when the data were obtained during the same experiment. We did not use statistical analyses if the experiments were performed on different days or if the sample number was only two.

\section{Results}

\subsection{A. lavenia Contains a High Amount of $11 \alpha O H-K A$}

We previously reported that the ethanol extract of $P$. disper Kunze leaves, prepared with 10 volumes of dry weight $(v / w)$ ethanol, efficiently inhibited melanogenesis in B16F10 cells, even after a 1/1000 dilution [5]. To compare the efficacy of the water extracts of $A$. lavenia dried leaves and that of the water extracts of $P$. disper Kunze leaves, we prepared the extracts ( 20 volumes of water $(v / w$ dried leaves)) and added them into the cultured medium together with forskolin (melanogenesis inducer-a cAMP agonist). Both extracts efficiently inhibited melanin synthesis even at 1/1000 dilution, when the melanin content was visually evaluated (Figure 2A). The melanin content was measured after $\mathrm{NaOH}$ extraction (Figure 2B). At 1/3000 dilution, the A. lavenia extract decreased the melanin content by $69 \%$ compared to the control (Fsk only), and the P. disper Kunze extract decreased the melanin content by $41 \%$. At $1 / 1000$ dilution, A. lavenia extract decreased the melanin content completely, while the P. disper Kunze extract decreased the melanin content by $60 \%$. This difference was not observed when the extracts were diluted at $1 / 300$. 
A

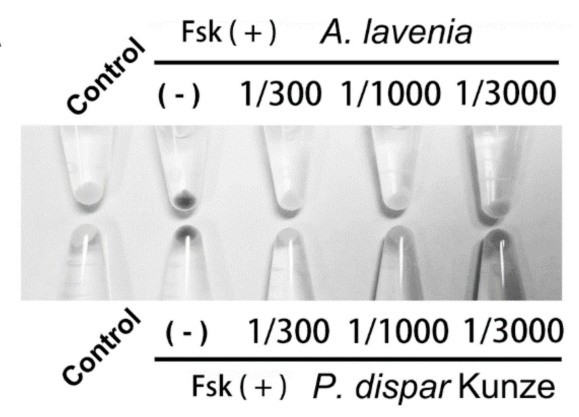

C A. lavenia

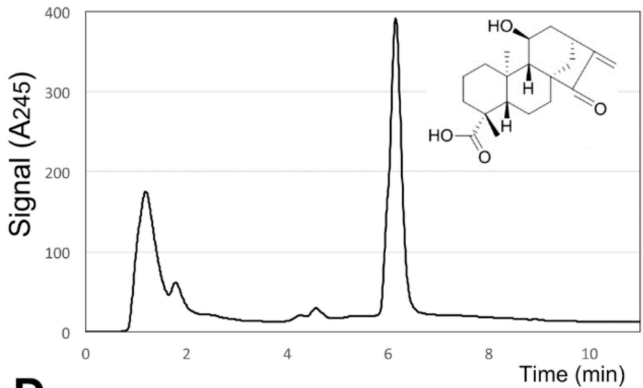

D

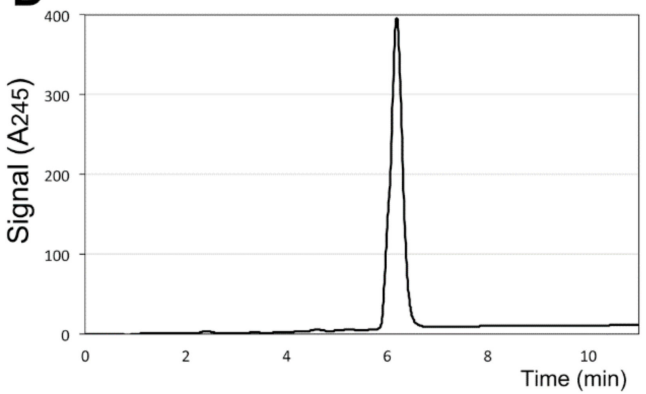

B

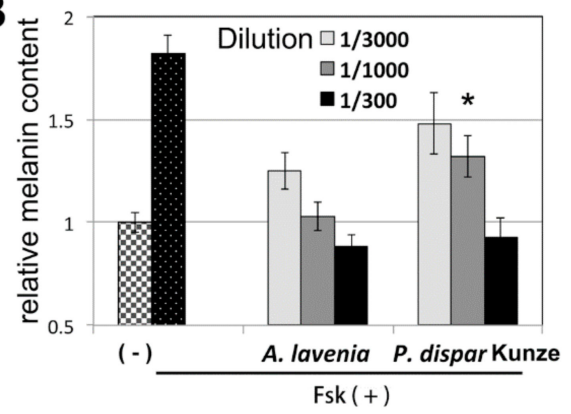

P. dispar Kunze

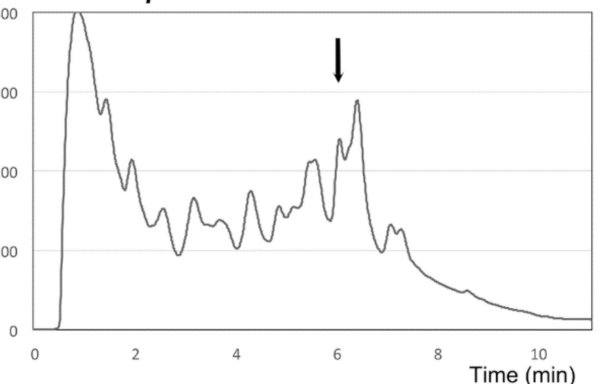

E

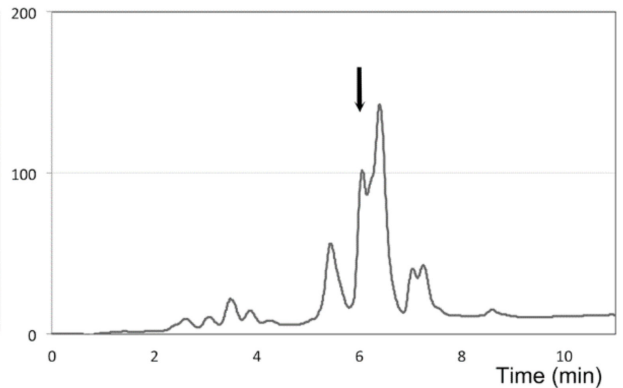

\begin{tabular}{|c|c|c|c|}
\cline { 2 - 4 } \multicolumn{1}{c|}{$/ \mathrm{g}$ dry leaves } & Water ext. $(\mathrm{mg})$ & $\mathrm{CHCl} 3$ ext. $(\mathrm{mg})$ & Purity $(\%)$ \\
\hline A. lavenia & $25.5 \pm 1.3$ & $24.1 \pm 0.72$ & $(87.4 \pm 1.1)$ \\
\hline P. dispar Kunze & $1.7 \pm 0.33$ & $1.2 \pm 0.19$ & $(2.2 \pm 0.3)$ \\
\hline
\end{tabular}

Figure 2. (A) B16F10 cells were treated with water extracts of A. lavenia and P. dispar Kunze (prepared with 20 volumes of water) at the indicated fold dilution $(1 / 300,1 / 1000,1 / 3000)$ in the medium. When the water extracts were dried, $1 \mathrm{~mL}$ extracts from A. lavenia and P. dispar Kunze dried leaves (50 mg each) produced approximately $9 \mathrm{mg}$ and $12 \mathrm{mg}$ of precipitants, respectively. Thus, the 1/1000 dilution produced $9 \mu \mathrm{g} / \mathrm{mL}$ and $12 \mu \mathrm{g} / \mathrm{mL}$, respectively. Melanogenesis was induced by $20 \mu \mathrm{M}$ of forskolin (Fsk) for $48 \mathrm{~h}$. (B) Melanin content was measured at $\mathrm{OD}_{405}$ after $\mathrm{NaOH}$ extraction. The values were first normalized by the total protein, and the relative content in the control (without forskolin) was set to 1. The means and SD are indicated, $n=3$. * indicates $p<0.05$ between A. lavenia and P. disper Kunze. (C) LC-UV analyses of the water extracts. An arrow indicates a peak for the candidate of $11 \alpha \mathrm{OH}-\mathrm{KA}$ that was detected by LC-MS (see Materials and Methods). (D) LC-UV analyses of water extracts after purification with 1 volume of $\mathrm{CHCl}_{3}$. (E) A summary of $11 \alpha \mathrm{OH}-\mathrm{KA}$ content in the fractions of water extracts (prepared from $1 \mathrm{~g}$ leaves with 2 times 20 volumes of water) and those followed by $\mathrm{CHCl}_{3}$ extraction. The purity of $11 \alpha \mathrm{OH}-\mathrm{KA}$ in the final fractions (water followed by $\mathrm{CHCl}_{3}$ ) was calculated from the total dry weight of the final fractions ( $27.5 \mathrm{mg}$ and $54.5 \mathrm{mg}$, respectively).

The LC-UV analyses suggested that $11 \alpha \mathrm{OH}-\mathrm{KA}$ was the major component in the A. lavenia water extract (Figure 2C, left). In contrast, no clear peak for $11 \alpha \mathrm{OH}-\mathrm{KA}$ was detected when the $P$. disper Kunze extract was analyzed (Figure 2C, right). The LC-MS analyses suggested that the peak indicated by an arrow corresponded to $11 \alpha \mathrm{OH}-\mathrm{KA}$ (data not shown). These results indicate that 
$11 \alpha \mathrm{OH}-\mathrm{KA}$ might be the major component responsible for melanogenesis inhibition in A. lavenia extract, while derivatives like glycosylated forms [5] might preferentially contribute to melanin inhibition in P. disper Kunze extract.

Next, we tried to purify $11 \alpha \mathrm{OH}-\mathrm{KA}$ by distribution. $\mathrm{CHCl}_{3}$ was able to extract $11 \alpha \mathrm{OH}-\mathrm{KA}$ from the above A. lavenia water extract with a high purity (more than $87 \%$ ) (Figure 2D, left). The spectra of the NMR analyses of the crystallized substance in $\mathrm{CHCl}_{3}$ were identical to those of the authentic $11 \alpha \mathrm{OH}-\mathrm{KA}$ (see Materials and Methods). In contrast, a large number of unknown compounds were extracted from the $P$. disper Kunze water extract (Figure 2D, right). A summary of the LC analyses is indicated in Figure 2E, suggesting that A. lavenia is an attractive source of $11 \alpha \mathrm{OH}-\mathrm{KA}$.

\subsection{Suitable Extraction of $11 \alpha \mathrm{OH}-\mathrm{KA}$ from A. lavenia}

According to information found on the Internet, all portions (leaf, stem, and root) of A. lavenia are used as herbal medicines in China and Taiwan. To determine the best conditions for $11 \alpha \mathrm{OH}-\mathrm{KA}$ extraction from A. lavenia, we first examined which portions of the plant are rich in this compound. Water extracts were prepared from leaves alone or from aerial parts. The melanogenesis assay on the B16F10 cells showed that the extract prepared from the aerial parts (stems and leaves) had less anti-melanogenic activity than that prepared from the leaves alone (Figure $3 \mathrm{~A}$, left). This suggests that stems (which account for more than $90 \%$ of the dry weight) contain less $11 \alpha \mathrm{OH}-\mathrm{KA}$, which was confirmed by the LC-UV analyses (Figure 3A, right).

Next, we examined how many volumes of water should be used for the extraction. Apparently, a small volume of water (10-fold) could enrich $11 \alpha \mathrm{OH}-\mathrm{KA}$ (Figure 3B). We speculated that the low solubility of $11 \alpha \mathrm{OH}-\mathrm{KA}$ in water might help retain this compound in residues. A maximum recovery of $11 \alpha \mathrm{OH}-\mathrm{KA}$ in water was observed when more than 30 volumes of water were used (Figure 3C). Therefore, considering the maximum recovery and enrichment of $11 \alpha \mathrm{OH}-\mathrm{KA}$ in water, we used 30 volumes of water in later experiments.

In China and Taiwan, A. lavenia is extracted in hot water, through which the thermal stability of $11 \alpha \mathrm{OH}-\mathrm{KA}$ was examined. The water extracts were incubated at $90^{\circ} \mathrm{C}$ or $120^{\circ} \mathrm{C}$ for 10 or $20 \mathrm{~min}$, and the $11 \alpha \mathrm{OH}-\mathrm{KA}$ content was analyzed by LC-UV. These thermal treatments produced a large amount of sedimentation, likely consisting of denatured protein. The $11 \alpha \mathrm{OH}-\mathrm{KA}$ contents in the soluble fraction were apparently increased (Figure 3D), which might be a result of the removal of the sedimented materials.

3.2.1. $\alpha \mathrm{OH}-\mathrm{KA}$ Is the Compound in A. lavenia Water Extract Responsible for Anti-Melanogenic Activity in B16F10 Cells

When $1 \mathrm{~g}$ of leaf was extracted in 30 volumes of water, the content of $11 \alpha \mathrm{OH}-\mathrm{KA}$ was approximately $0.6 \mathrm{mg} / \mathrm{mL}(1.8 \mathrm{mM})$. To determine the degree of the contribution of $11 \alpha \mathrm{OH}-\mathrm{KA}$ in the A. lavenia water extract to the anti-melanogenic activity, different concentrations of authentic $11 \alpha \mathrm{OH}-\mathrm{KA}$ were tested in B16F10 cells. Visual examination (Figure 4A) and the measurement of melanin content (Figure 4B) revealed that the water extracts (Figure $4 \mathrm{~A}$, upper set) that showed the same efficacy in terms of anti-melanogenic activity as authentic $11 \alpha \mathrm{OH}-\mathrm{KA}$ alone (Figure $4 \mathrm{~A}$, lower set) contained only a half amount of $11 \alpha \mathrm{OH}-\mathrm{KA}$. These results suggest that the $11 \alpha \mathrm{OH}-\mathrm{KA}$ in the extract contributed to almost $50 \%$ of the extract's anti-melanogenic activity. The other $50 \%$ might be derived from $11 \alpha \mathrm{OH}-\mathrm{KA}$ derivatives, such as glycoside forms, which might also explain the low content of $11 \alpha \mathrm{OH}-\mathrm{KA}$ in the P. disper Kunze extract despite its high efficacy in terms of anti-melanogenic activity (Figure 2).

3.2.2. $\alpha \mathrm{OH}-\mathrm{KA}$ Is the Compound in A. lavenia Extract Responsible for Anti-Melanogenic Activity in Mice

To obtain preliminary results for the future development of A. lavenia as a material for cosmetics, we performed in vivo analyses using a small number of mice. We first examined the pharmacokinetics of $11 \alpha \mathrm{OH}-\mathrm{KA}$ in mice. The water intake was approximately $4 \mathrm{~mL}$ daily in mice with approximately 
$25 \mathrm{~g}$ bodyweight. The maximum solubility of the $11 \alpha \mathrm{OH}-\mathrm{KA}$ in the water extract of $A$. lavenia (see Figure 3C, 20-30 volumes water: $0.6 \mathrm{mg} / \mathrm{mL}$ ) could theoretically provide a $100 \mathrm{mg} / \mathrm{kg}$ daily dose of this kaurenoic acid ( $4 \mathrm{~mL}$ of $0.6 \mathrm{mg} / \mathrm{mL} 11 \alpha \mathrm{OH}-\mathrm{KA}$ made $2.4 \mathrm{mg} /$ day; normalization of $2.4 \mathrm{mg}$ by mouse body weight $(25 \mathrm{~g})$ resulted in $96 \mathrm{mg} / \mathrm{kg}$ ). Therefore, we decided to treat the mice with $100 \mathrm{mg} / \mathrm{kg}$ $11 \alpha \mathrm{OH}-\mathrm{KA}$ (suspended in $200 \mu \mathrm{L}$ of $1 \%$ Tween 80 ).

Oral treatment with $11 \alpha \mathrm{OH}-\mathrm{KA}$ resulted in its rapid appearance (within $15 \mathrm{~min}$ ) in the blood (Figure 5A). The concentration reached and retained an effective dose in the B16F10 cells. This result indicates that $11 \alpha \mathrm{OH}-\mathrm{KA}$ could be absorbed through the digestive tract. However, the fact that the concentration decreased within 60 min suggests rapid excretion of this compound.

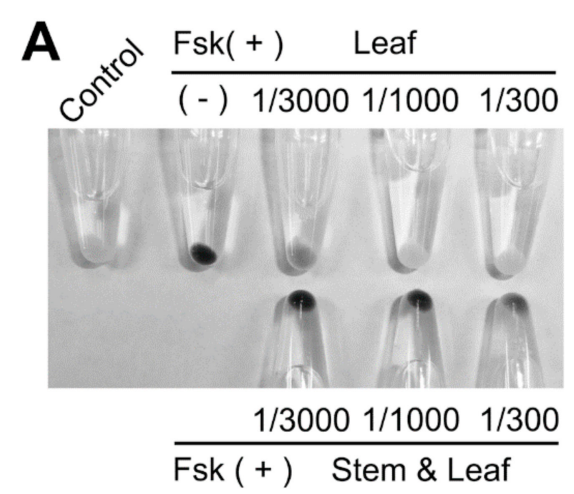

B
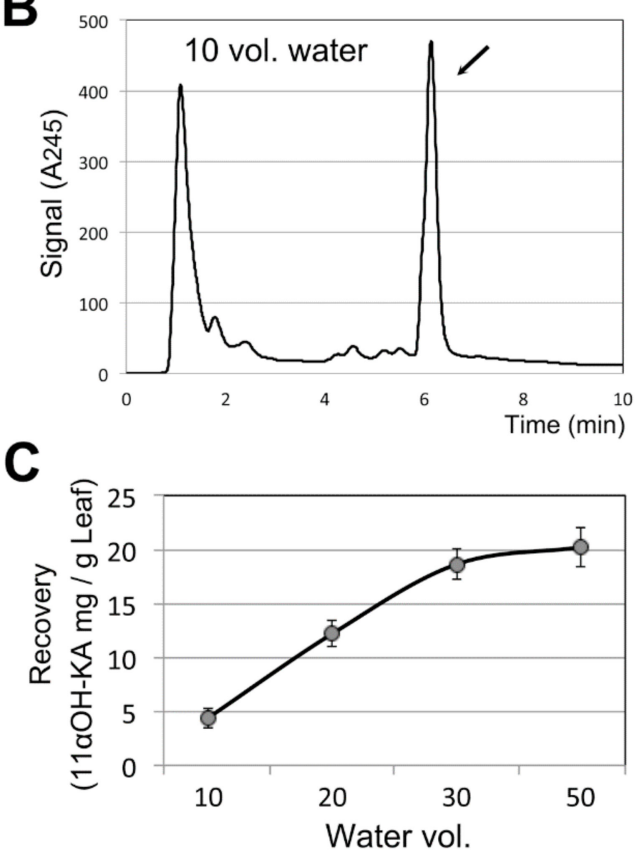
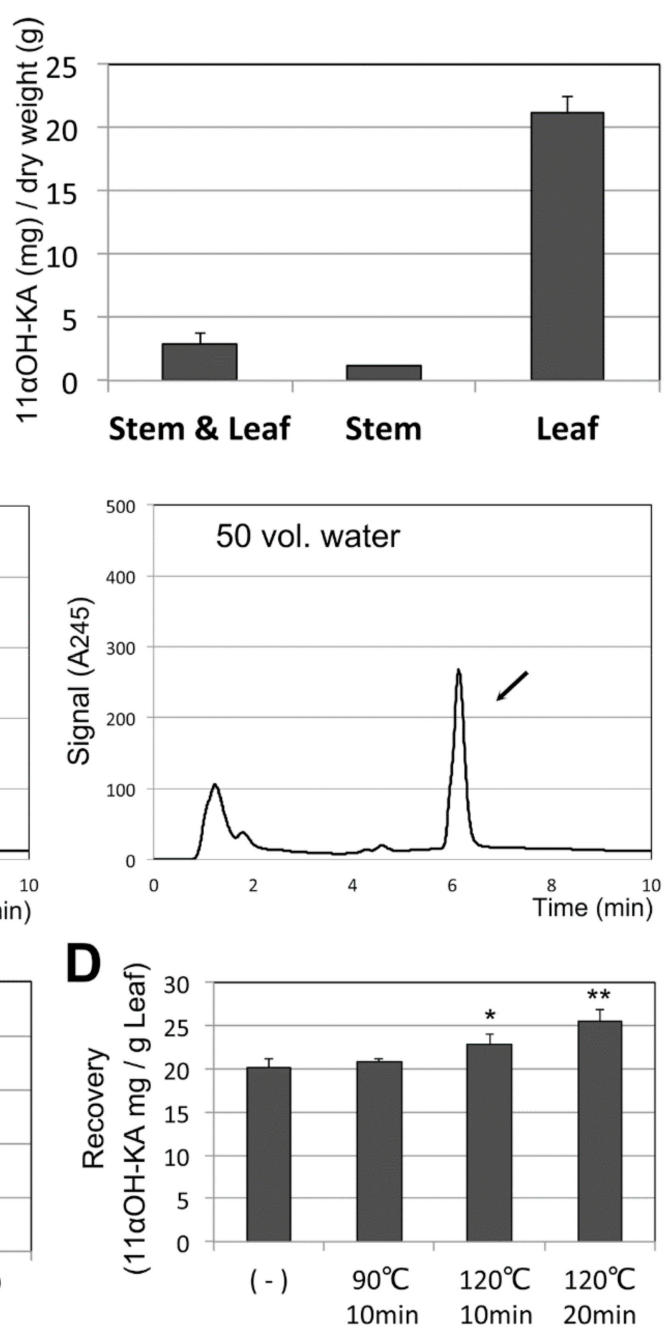

Figure 3. (A) Leaves alone and with stems were dried and extracted with 20 volumes of water. B16F10 cells were treated with these extracts at the indicated dilution (left). One gram of dried A. lavenia (different portions) was extracted twice with 20 volumes of water, and the $11 \alpha \mathrm{OH}-\mathrm{KA}$ content was measured (right). The means and SD are indicated, $n=3$. (B) LC-UV analysis of A. lavenia leaves extracted with 10 volumes (left) and 50 volumes (right) of water. Arrows indicate $11 \alpha \mathrm{OH}-\mathrm{KA}$. (C) One gram of dried A. lavenia leaf was extracted once with the indicated volumes of water, and the recovery of $11 \alpha \mathrm{OH}-\mathrm{KA}$ was calculated after the LC-UV analyses $(n=2)$. (D) Extracts (30 volumes of water) were incubated at the indicated temperatures and times, with the analyses performed by LC-UV. * and ** indicate $p<0.05$ and $p<0.01$, respectively $(n=3)$. 

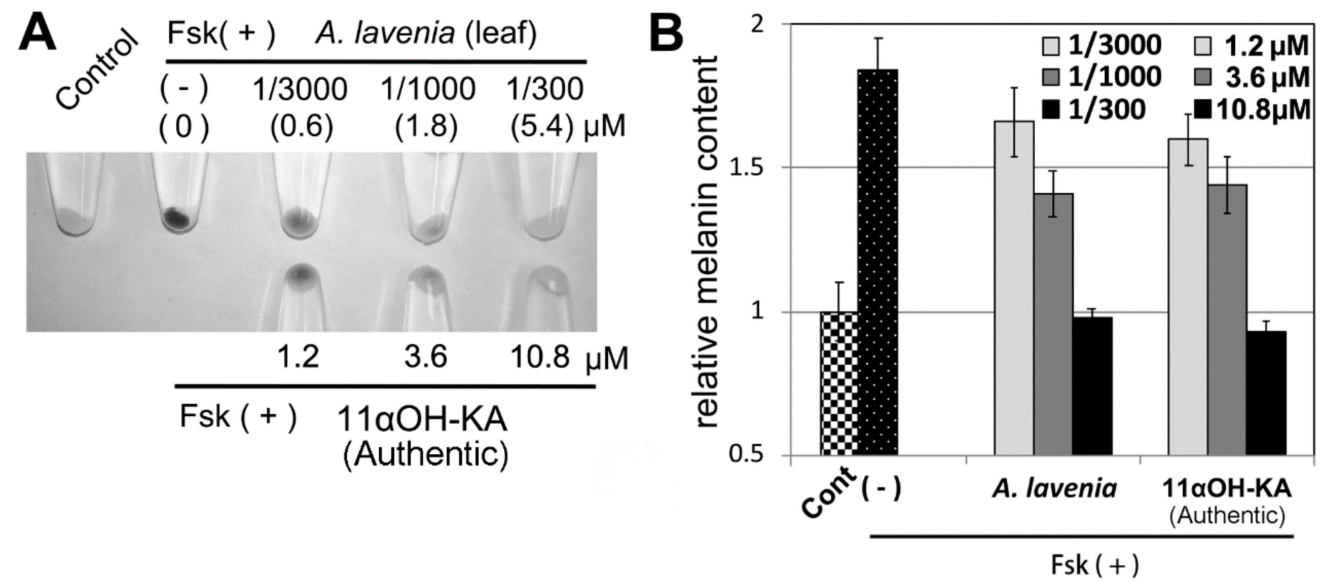

Figure 4. (A) A. lavenia leaves were extracted with 30 volumes of water and incubated at $120{ }^{\circ} \mathrm{C}$ for $20 \mathrm{~min}$. After measurement of the $11 \alpha \mathrm{OH}-\mathrm{KA}$ content in the extract, the extracts (upper: actual concentrations of $11 \alpha \mathrm{OH}-\mathrm{KA}$ from the extract are indicated in brackets) and authentic $11 \alpha \mathrm{OH}-\mathrm{KA}$ with a 1/10-10-fold concentration were subjected to a melanogenesis inhibitory assay in the B16F10 cells. By visual examination, we selected sets of cells showing the same levels of melanin content (lower). (B) The melanin content in the A: extract and authentic samples was thus measured. The means and SD are indicted, $n=3$.
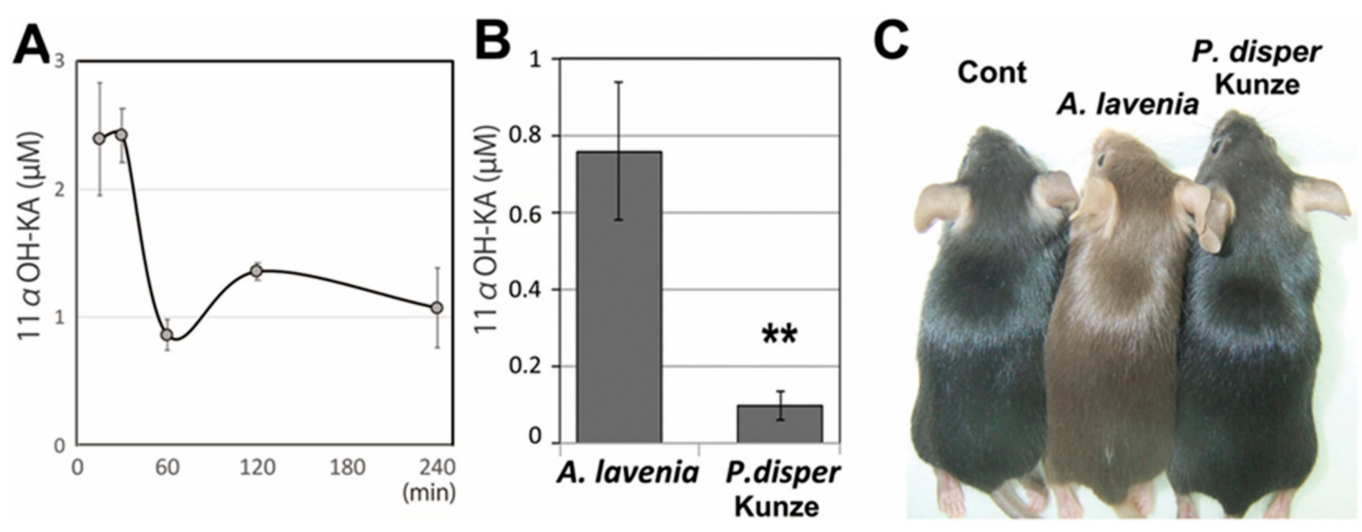

Figure 5. (A) Mice were orally administrated $11 \alpha \mathrm{OH}-\mathrm{KA}(100 \mathrm{mg} / \mathrm{kg})$, and their blood was collected at the indicated time. The $11 \alpha \mathrm{OH}-\mathrm{KA}$ contents were measured by LC-MS analyses. The means and SD are indicted $(n=3)$. (B) Mice were treated with A. lavenia or P. dispar Kunze leaf extracts in drinking water (a twofold dilution of the extract which was prepared by the same methods in Figure $4 \mathrm{~A}$ ) for one week, and blood was collected for $11 \alpha \mathrm{OH}-\mathrm{KA}$ measurement $(n=3)$. The means and SD are shown. ** indicates $p<0.01$. (C) Three-week-old mice ( $n=2$; see also Supplementary Materials Figure S4) were treated with the water extract (in Figure 5B) for two weeks, and then the pigmentation in the newly grown hair was examined by photography.

Next, we examined the chronic effects of $11 \alpha \mathrm{OH}-\mathrm{KA}$ in mice. Since even $0.6 \mathrm{mg} / \mathrm{mL}$ of $11 \alpha \mathrm{OH}-\mathrm{KA}$ rapidly precipitated in drinking water if $11 \alpha \mathrm{OH}-\mathrm{KA}$ was pure, we decided to test the $A$. lavenia water extract. However, the $A$. lavenia water extract might contain unknown ingredients with a bitter taste. Therefore, the extract had to be further diluted with two volumes of water (with a final value of $0.3 \mathrm{mg} / \mathrm{mL}$ for $11 \alpha \mathrm{OH}-\mathrm{KA}$, approximately $50 \mathrm{mg} / \mathrm{kg} /$ day). The mice were treated with the water extracts for 1 week, and their blood samples were then collected (Figure 5B). LC-MS analyses detected $11 \alpha \mathrm{OH}-\mathrm{KA}$ in the blood at a semi-effective concentration. The P. dispar Kunze water extract that had been prepared by the same procedure as the A. lavenia water extract was also examined. The content of 
$11 \alpha \mathrm{OH}-\mathrm{KA}$ in the blood of mice treated with the P. dispar Kunze extract was 10 times lower than that of the mice treated with the A. lavenia extract.

In adult mice, hair growth pauses during the telogen stage for several months, and new growth (anagen) randomly occurs during only a few days in different areas [27]. Therefore, to examine the effect of melanogenesis inhibitors, the duration of the treatment with compounds (inhibitors) should be long (e.g., several months). In contrast, downy hairs are synchronously replaced with adult hairs during the 3-4-week-old (W) phase. Therefore, when $3 \mathrm{~W}$ mice are treated with inhibitors for 2 weeks, the effects on melanogenesis can be evaluated from the pigmentation (color) of the newly grown hair (i.e., the first adult hair) at 5W-6W [28].

When mice were treated with A. lavenia extract via drinking water for two weeks $(3 \mathrm{~W}-4 \mathrm{~W})$, their pigmentation was suppressed in the newly grown hairs (Figure 5C). In contrast, their eye pigmentation was not affected. The suppression of hair pigmentation was not observed in the mice treated with the $P$. dispar Kunze extract. These results suggest that the A. lavenia leaf extract might contain anti-melanogenic substances, possibly $11 \alpha \mathrm{OH}-\mathrm{KA}$, that are effective in vivo, whereas the P. dispar Kunze leaf extract, likely rich in $11 \alpha \mathrm{OH}-\mathrm{KA}$ derivatives, might not be effective in vivo.

\section{Discussion}

We found that A. lavenia leaves contained a high amount of $11 \alpha \mathrm{OH}-\mathrm{KA}$ (approximately $2.5 \%$ of dry leaf weight). Water efficiently extracted $11 \alpha \mathrm{OH}-\mathrm{KA}$, despite the hydrophobic nature of this compound. As $11 \alpha \mathrm{OH}-\mathrm{KA}$ in water was stable at $120^{\circ} \mathrm{C}$ for $20 \mathrm{~min}$, we sterilized the water extract of A. lavenia leaf and administered it to mice. The results confirmed the presence of $11 \alpha \mathrm{OH}-\mathrm{KA}$ in the mice's blood and the potency of the water extract as an anti-melanogenic reagent in vivo.

The presence of $11 \alpha \mathrm{OH}-\mathrm{KA}$ and its derivatives in A. lavenia was reported in 1979 [16] and 1990 [29]. Since then, only one study from Indonesia has reported a comprehensive analysis of the ingredients in A. lavenia [30]. However, no $11 \alpha \mathrm{OH}-\mathrm{KA}$ was identified in those materials. Moreover, no studies on the physical properties of $11 \alpha \mathrm{OH}-\mathrm{KA}$, which can be extracted by pure water from A. lavenia, have been found.

A review article about folk remedies in India refers to A. lavenia water extract as a treatment for digestive system disorders [31]. An Internet search for "A. lavenia" or its Chinese name suggested some beneficial uses of this plant as an anti-inflammatory herbal medicine via a hot water extract (i.e., as a decoction) (e.g., for hepatitis, pulmonary inflammation (allergy and chronic obstructive pulmonary disease), and skin inflammation). However, no formal reports on the biological activities of A. lavenia extracts or the ecological status of this plant were found in PubMed. In our city (Gifu, Japan), A. lavenia is listed as an endangered species. The rarity of $A$. lavenia may make it difficult to analyze and develop its potential as an herbal medicine and a functional food.

On the other hand, the beneficial potential of $11 \alpha \mathrm{OH}-\mathrm{KA}$, purified from P. semipinnata, has been determined in vitro and in vivo [8-11]. Although we did not examine the content of $11 \alpha \mathrm{OH}-\mathrm{KA}$ in $P$. semipinnata, we guess that this content may not be very high compared with that in $A$. lavenia because $P$. semipinnata is closely related to $P$. disper Kunze. In addition, there are no records on the use of these ferns in human subjects, even on the Internet. This background suggests that $A$. lavenia may have greater potential as a herbal medicine than these ferns if $11 \alpha \mathrm{OH}-\mathrm{KA}$ is shown to have clinical potential.

Studies on the potential of $11 \alpha \mathrm{OH}-\mathrm{KA}$ have been focused on its activities as an anti-cancer $[2,10,11,32]$ and anti-inflammatory [11,33] agent. However, it is also true that the doses of $11 \alpha \mathrm{OH}-\mathrm{KA}$ required for these activities are more than $20 \mu \mathrm{M}$, which is relatively high. In contrast, at a concentration of less than $1 \mu \mathrm{M}$, the kaurene ent-11 $\alpha$-hydroxy-16-kauren-15-one, which has a methyl group in the 19-position instead of the carboxyl group in $11 \alpha \mathrm{OH}-\mathrm{KA}$, shows high apoptotic activity against human HL-60 monocytes [12]. These differences suggest that the 19-position may be a determinant of cellular toxicity [5].

Although anti-tumor and anti-inflammatory activities are found in a variety of kaurens [7,34-36], the specific feature of $11 \alpha \mathrm{OH}-\mathrm{KA}$ is a type of anti-melanogenic activity [5]. A number of natural 
compounds, such as flavonoids and terpenoids, have been found to modulate melanogenesis by altering the expression of microphthalmia transcription factor (MITF), which is essential for melanogenic programs $[13,14]$. In contrast to these compounds, no MITF modulators have been found in kaurens or kaurenoic acids.

$11 \alpha \mathrm{OH}-\mathrm{KA}$ suppresses the expression of the tyrosinase gene by downregulating its promoter activity. Although $11 \alpha \mathrm{OH}-\mathrm{KA}$ does not alter the expression or activity levels of MITF, $11 \alpha \mathrm{OH}-\mathrm{KA}$ suppresses tyrosinase gene promoter activity in an MITF-binding-element-dependent manner [5]. Interestingly, the overexpression of MITF in B16F10 cells results in a cancellation of the $11 \alpha \mathrm{OH}-\mathrm{KA}-$ mediated suppression of tyrosinase promoter activity, suggesting that $11 \alpha \mathrm{OH}-\mathrm{KA}$ may recruit an unknown repressor to the MITF-binding element. Moreover, the mechanism by which $11 \alpha \mathrm{OH}-\mathrm{KA}$ suppresses tyrosinase promoter activity may be different from that which leads to cytotoxicity because anti-melanogenic activity is observed even when B16F10 cells are treated with $1.2 \mu \mathrm{M}$ of $11 \alpha \mathrm{OH}-\mathrm{KA}$ (Figure 4).

Research involving a human three-dimensional skin model composed of primary keratinocytes and melanocytes suggests that the topical use of $1 \mathrm{mM}$ of $11 \alpha \mathrm{OH}-\mathrm{KA}$ completely suppresses skin pigmentation [5]. In terms of anti-melanogenic activity, $1 \mathrm{mM}$ of $11 \alpha \mathrm{OH}-\mathrm{KA}$ is equivalent to approximately $6.6 \mathrm{mg} / \mathrm{mL}(0.66 \%)$ of dried A. lavenia leaf (Figure 3). In this context, A. lavenia is an attractive source of cosmetic items for skin whitening. In addition, $A$. lavenia is used as a folk medicine, and $11 \alpha \mathrm{OH}-\mathrm{KA}$ has a wide margin between its effective doses (concentrations) for anti-melanogenic activity and cytotoxicity.

Importantly, tranexamic acid (a hemostatic drug) has been found to suppress melanin deposition in human skin and is used as an oral medicine to treat melasma [23,24]. Interestingly, the fur of mice treated with tranexamic acid changed color from black to brown [37]. In the present study, we have also shown that a water extract of A. lavenia leaf can efficiently suppress hair pigmentation (black to brown) in mice when given orally, suggesting that $A$. lavenia leaf could be developed into both internal cosmetics and functional foods [20-22] for patients suffering from melasma. Further studies are needed regarding the cellular targets of $A$. lavenia extracts and $11 \alpha \mathrm{OH}-\mathrm{KA}$, as well as their safety.

Supplementary Materials: The following are available online at http://www.mdpi.com/2304-8158/9/1/73/s1.

Author Contributions: A.H. and R.I. performed the cell experiments; M.M. and M.H. purified and analyzed $11 \alpha \mathrm{OH}-\mathrm{KA}$; A.H., M.M., and S.T. performed the LC-MS analyses and the quantification of $11 \alpha \mathrm{OH}-\mathrm{KA} ; \mathrm{H} . \mathrm{T}$. performed the mouse experiments; E.H. and M.K. performed the NMR analyses; H.T. wrote the manuscript. All authors have read and agreed to the published version of the manuscript.

Funding: A part of this research was supported by grants from Gifu University (COC project), the Japanese Foundation for Applied Enzymology (H30), the Ogawa Science and Technology Foundation (H30), the Koshiyama Research Grant (H30, R1), and Gifu City (R1-2).

Acknowledgments: The authors would like to thank Tsugumi Aoe, Saki Shimabayashi, Hironari Ito, Shiniya Kato, and Kenta Isogawa for their technical assistance with the experiments.

Conflicts of Interest: The authors declare no conflict of interest.

\section{References}

1. Lee, C.C.; Dudonne, S.; Kim, J.H.; Kim, J.S.; Dube, P.; Kim, J.E.; Desjardins, Y.; Park, J.H.Y.; Lee, K.W.; Lee, C.Y. A major daidzin metabolite 7,8,4'-trihydroxyisoflavone found in the plasma of soybean extract-fed rats attenuates monocyte-endothelial cell adhesion. Food Chem. 2018, 240, 607-614. [CrossRef]

2. Li, J.H.; He, C.W.; Liang, N.C.; Mo, L.E.; Zhang, X. Effects of antitumor compounds isolated from Pteris semipinnata L on DNA topoisomerases and cell cycle of HL-60 cells. Zhongguo Yao Li Xue Bao 1999, 20, 541-545.

3. Wang, F.; Li, Y.J.; Ren, F.C.; Wei, G.Z.; Liu, J.K. Pterisolic acids A-F, new ent-kaurane diterpenoids from the fern Pteris semipinnata. Chem. Pharm. Bull. (Tokyo) 2011, 59, 484-487. [CrossRef] [PubMed]

4. Qiu, M.; Yang, B.; Cao, D.; Zhu, J.; Jin, J.; Chen, Y.; Lian, Z.; Luo, X.; Zhao, Z. Two new hydroxylated ent-kauranoic acids from Pteris semipinnata. Phytochem. Lett. 2016, 16, 156-162. [CrossRef] 
5. Kuroi, A.; Sugimura, K.; Kumagai, A.; Kohara, A.; Nagaoka, Y.; Kawahara, H.; Yamahara, M.; Kawahara, N.; Takemori, H.; Fuchino, H. The Importance of 11alpha-OH, 15-oxo, and 16-en Moieties of 11alpha-Hydroxy-15-oxo-kaur-16-en-19-oic Acid in Its Inhibitory Activity on Melanogenesis. Skin Pharmacol. Physiol. 2017, 30, 205-215. [CrossRef]

6. Tanaka, N.; Murakami, T.; Saiki, Y.; Chen, C.-M.; Luis, D.; Gomez, P. Chemical and chemotaxonomical studies of ferns. Chem. Pharm. Bull. (Tokyo) 1981, 29, 3455-3463. [CrossRef]

7. Zhang, M.; Zhao, C.; Dai, W.; He, J.; Jiao, S.; Li, B. Anti-inflammatory ent-kaurenoic acids and their glycosides from Gochnatia decora. Phytochemistry 2017, 137, 174-181. [CrossRef] [PubMed]

8. Chen, G.G.; Liang, N.C.; Lee, J.F.; Chan, U.P.; Wang, S.H.; Leung, B.C.; Leung, K.L. Over-expression of Bcl-2 against Pteris semipinnata L-induced apoptosis of human colon cancer cells via a NF-kappa B-related pathway. Apoptosis 2004, 9, 619-627. [CrossRef] [PubMed]

9. Liu, Z.M.; Chen, G.G.; Vlantis, A.C.; Liang, N.C.; Deng, Y.F.; van Hasselt, C.A. Cell death induced by ent-11alpha-hydroxy-15-oxo-kaur-16-en-19-oic-acid in anaplastic thyroid carcinoma cells is via a mitochondrial-mediated pathway. Apoptosis 2005, 10, 1345-1356. [CrossRef]

10. Li, M.Y.; Leung, J.; Kong, A.W.; Liang, N.C.; Wu, K.; Hsin, M.K.; Deng, Y.F.; Gong, X.; Lv, Y.; Mok, T.S.; et al. Anticancer efficacy of $5 \mathrm{~F}$ in NNK-induced lung cancer development of $\mathrm{A} / \mathrm{J}$ mice and human lung cancer cells. J. Mol. Med. (Berl) 2010, 88, 1265-1276. [CrossRef]

11. Ye, H.; Wu, Q.; Guo, M.; Wu, K.; Lv, Y.; Yu, F.; Liu, Y.; Gao, X.; Zhu, Y.; Cui, L.; et al. Growth inhibition effects of ent-11alpha-hydroxy-15-oxo-kaur-16-en-19-oic-acid on colorectal carcinoma cells and colon carcinoma-bearing mice. Mol. Med. Rep. 2016, 13, 3525-3532. [CrossRef] [PubMed]

12. Kondoh, M.; Suzuki, I.; Sato, M.; Nagashima, F.; Simizu, S.; Harada, M.; Fujii, M.; Osada, H.; Asakawa, Y.; Watanabe, Y. Kaurene diterpene induces apoptosis in human leukemia cells partly through a caspase-8-dependent pathway. J. Pharmacol. Exp. Ther. 2004, 311, 115-122. [CrossRef] [PubMed]

13. Niu, C.; Aisa, H.A. Upregulation of Melanogenesis and Tyrosinase Activity: Potential Agents for Vitiligo. Molecules 2017, 22, 1303. [CrossRef] [PubMed]

14. Panzella, L.; Napolitano, A. Natural and Bioinspired Phenolic Compounds as Tyrosinase Inhibitors for the Treatment of Skin Hyperpigmentation: Recent Advances. Cosmetics 2019, 6, 57. [CrossRef]

15. Wu, J.; Meng, L.; Long, M.; Ruan, Y.; Li, X.; Huang, Y.; Qiu, W. Inhibition of breast cancer cell growth by the Pteris semipinnata extract ent-11alpha-hydroxy-15-oxo-kaur-16-en-19-oic-acid. Oncol. Lett. 2017, 14, 6809-6814. [CrossRef] [PubMed]

16. Cheng, P.C.; Hufford, C.D.; Doorenbos, N.J. Isolation of 11-Hydroxyated Kauranic Acids From Adenostemma lavenia. J. Nat. Prod. 1979, 42, 183-186. [CrossRef]

17. Salvo, A.; La Torre, G.L.; Mangano, V.; Casale, K.E.; Bartolomeo, G.; Santini, A.; Granata, T.; Dugo, G. Toxic inorganic pollutants in foods from agricultural producing areas of Southern Italy: Level and risk assessment. Ecotoxicol. Environ. Saf. 2018, 148, 114-124. [CrossRef]

18. Mikusova, P.; Srobarova, A.; Sulyok, M.; Santini, A. Fusarium fungi and associated metabolites presence on grapes from Slovakia. Mycotoxin Res. 2013, 29, 97-102. [CrossRef]

19. Santini, A.; Ferracane, R.; Meca, G.; Ritieni, A. Overview of analytical methods for beauvericin and fusaproliferin in food matrices. Anal. Bioanal. Chem. 2009, 395, 1253-1260. [CrossRef]

20. Hardy, G. Nutraceuticals and functional foods: Introduction and meaning. Nutrition 2000, 16, 688-689. [CrossRef]

21. Santini, A.; Novellino, E. To Nutraceuticals and Back: Rethinking a Concept. Foods 2017, 6, 74. [CrossRef]

22. Daliu, P.; Santini, A.; Novellino, E. A decade of nutraceutical patents: Where are we now in 2018? Expert Opin. Ther. Pat. 2018, 28, 875-882. [CrossRef] [PubMed]

23. Maeda, K.; Naganuma, M. Topical trans-4-aminomethylcyclohexanecarboxylic acid prevents ultraviolet radiation-induced pigmentation. J Photochem. Photobiol. B. 1998, 47, 136-141. [CrossRef]

24. Wang, J.V.; Jhawar, N.; Saedi, N. Tranexamic Acid for Melasma: Evaluating the Various Formulations. J Clin. Aesthet. Dermatol. 2019, 12, E73-E74.

25. Kanwal, N.; Siddiqui, A.J.; Haq, F.U.; El-Seedi, H.R.; Musharraf, S.G. Two-stage mass spectrometry approach for the analysis of triterpenoid glycosides in Fagonia indica. RSC Adv. 2018, 8, 41023-41031. [CrossRef]

26. Jiang, X.; Shen, Y.; Wang, H.; Wang, C.; Ye, X.; Xiang, Z. Determination of kaurenoic acid in rat plasma using UPLC-MS/MS and its application to a pharmacokinetic study. J. Pharm. Biomed. Anal. 2019, 164, 27-31. [CrossRef] 
27. Muller-Rover, S.; Handjiski, B.; van der Veen, C.; Eichmuller, S.; Foitzik, K.; McKay, I.A.; Stenn, K.S.; Paus, R. A comprehensive guide for the accurate classification of murine hair follicles in distinct hair cycle stages. J. Invest. Dermatol. 2001, 117, 3-15. [CrossRef]

28. Kumagai, A.; Horike, N.; Satoh, Y.; Uebi, T.; Sasaki, T.; Itoh, Y.; Hirata, Y.; Uchio-Yamada, K.; Kitagawa, K.; Uesato, S.; et al. A Potent Inhibitor of SIK2, 3, 3', 7-Trihydroxy-4'-Methoxyflavon (4'-O-Methylfisetin), Promotes Melanogenesis in B16F10 Melanoma Cells. PLoS ONE 2011, 6, e26148. [CrossRef]

29. Shimizu, S.; Miyase, T.; Umehara, K.; Ueno, A. Kaurane-type diterpenes from Adenostemma lavenia O. Kuntze. Chem. Pharm. Bull. (Tokyo) 1990, 38, 1308-1312. [CrossRef]

30. Fauzan, A.; Praseptiangga, D.; Hartanto, R.; Pujiasmanto, B. Characterization of the chemical composition of Adenostemma lavenia (L.) Kuntze and Adenostemma platyphyllum Cass. Earth Environ. Sci. 2018, 102, 012029. [CrossRef]

31. Davi Prasad, A.G.; Shyma, T.B.; Raghavendra, M.P. Plants used by the tribes for the treatment of digestive system disorders in Wayanad district, Kerala. J. Appl. Pharm. Sci. 2013, 3, 171-175.

32. Ye, H.; Yang, X.; Wu, K.; Li, L.; Lv, Y.; Liu, Y.; Zheng, X. Inhibitory effect of 5F on development of lung cancer in A/J mice. Int. J. Clin. Exp. Pathol. 2015, 8, 4138-4142. [PubMed]

33. Chen, G.G.; Leung, J.; Liang, N.C.; Li, L.; Wu, K.; Chan, U.P.; Leung, B.C.; Li, M.; Du, J.; Deng, Y.F.; et al. Ent-11alpha-hydroxy-15-oxo-kaur-16-en-19-oic-acid inhibits hepatocellular carcinoma in vitro and in vivo via stabilizing IkBalpha. Invest. New Drugs 2012, 30, 2210-2218. [CrossRef] [PubMed]

34. Ruiz, Y.; Rodrigues, J.; Arvelo, F.; Usubillaga, A.; Monsalve, M.; Diez, N.; Galindo-Castro, I. Cytotoxic and apoptosis-inducing effect of ent-15-oxo-kaur-16-en-19-oic acid, a derivative of grandiflorolic acid from Espeletia schultzii. Phytochemistry 2008, 69, 432-438. [CrossRef]

35. Li, D.; Du, Z.; Li, C.; Goodin, S.; Huang, H.; He, Y.; Zhang, Y.; Wang, H.; Zheng, X.; Zhang, K. Potent inhibitory effect of terpenoids from Acanthopanax trifoliatuson growth of PC-3 prostate cancer cellsin vitroandin vivo is associated with suppression of NF-KB and STAT3 signalling. J. Funct. Foods 2015, 15, 274-283. [CrossRef]

36. Kim, K.H.; Sadikot, R.T.; Joo, M. Therapeutic effect of ent-kaur-16-en-19-oic acid on neutrophilic lung inflammation and sepsis is mediated by Nrf2. Biochem. Biophys. Res. Commun. 2016, 474, 534-540. [CrossRef]

37. Hiramoto, K.; Yamate, Y.; Takishita, Y.; Sato, E.F. The Role of gp91phox and the Effect of Tranexamic Acid Administration on Hair Color in Mice. Int. J. Mol. Sci. 2019, 20, 2665. [CrossRef] 